\title{
DISCRICIONARIEDADE ADMINISTRATIVA E DEVER DE PROTEÇÃO DO MEIO AMBIENTE
}

\section{Annelise Monteiro Steigleder}

Mestranda em Direito pela UFPR, Promotora de Justiça/RS.

SUMÁRIO: Introdução; $1 \mathrm{O}$ direito ao meio ambiente equilibrado; 2 A eficácia do direito ao meio ambiente como um direito fundamental e a concepção de um mínimo vital em termos de qualidade ambiental; 3 A discricionariedade administrativa; $4 \mathrm{O}$ controle judicial da discricionariedade para a proteção do meio ambiente; Conclusão; Referências bibliográficas.

\section{INTRODUÇÃO}

A Constituição Federal de 1988, no seu art. 225, caput, alçou o direito ao meio ambiente ecologicamente equilibrado à categoria de direito fundamental da pessoa humana, assim entendido como pressuposto para os igualmente fundamentais direitos à vida e à saúde. Por força do art. $5^{\circ}, \S 1^{\circ}$, da Constituição, ${ }^{1}$ esse direito tem aplicação imediata.

O art. 225 também impõe ao Poder Público o dever de defender o meio ambiente e preservá-lo para as presentes e futuras gerações, o que também vem reforçado na Carta Constitucional no art. 23, que trata da competência comum da União, dos Estados, do Distrito Federal e dos Municípios para proteger o meio ambiente e combater a poluição em qualquer de suas formas (inc. V) e preservar as florestas, a fauna e a flora (inc. VII).

O exame desses dispositivos parece indicar a existência de um dever de o Poder Público adotar medidas administrativas para a proteção ambiental, o qual, se descumprido, poderia induzir responsabilização civil. Todavia, recentes arestos do Superior Tribunal de Justiça vêm invocando a seara da discricionariedade administrativa como óbice para que o Poder Judiciário possa impor ao Executivo obrigações de fazer e de não fazer que tutelem a qualidade ambiental.

Neste sentido, seguem as seguintes ementas:

"PROCESSUAL CIVIL - AGRAVO REGIMENTAL - RECURSO ESPECIAL - AÇÃO CIVIL PÚBLICA - MINISTÉRIO PÚBLICO CARÊNCIA DE AÇÃO - MUNICÍPIO - OBRA PARA PROTEÇÃO DO MEIO AMBIENTE

1. Não se empresta seguimento a recurso especial intentado para reformar acórdão que elegeu matéria constitucional como informe básico para a conclusão assentada.

1 Art. $5^{\circ}, \S 1^{\circ}$, Constituição Federal de 1988: "as normas definidoras e direitos e garantias fundamentais têm aplicação imediata". 
2. Em tese, pode a Administração Pública figurar no pólo passivo da ação civil pública e até ser condenada ao cumprimento da obrigação de fazer ou deixar de fazer.

3. $\mathrm{O}$ art. $3^{\circ}$, da Lei $\mathrm{n}^{\circ} 7.347 / 85$, a ser aplicado contra a Administração Pública, há de ser interpretado como vinculado aos princípios constitucionais que regem a Administração Pública, especialmente o que outorga ao Poder Executivo 'o gozo de total liberdade e discricionariedade para eleger as obras prioritárias a serem realizadas, ditando a oportunidade e conveniência desta ou daquela obra, não sendo dado ao Poder Judiciário obrigá-lo a dar prioridade a determinada tarefa do Poder Público' (trecho do acórdão).

4. Matéria constitucional sublimada, essencialmente, no aresto que não cabe ser examinada em sede de recurso especial.

5. Agravo regimental improvido."

“ADMINISTRATIVO - PROCESSO CIVIL - AÇÃO CIVIL PÚBLICA

1. O Ministério Público está legitimado para propor ação civil pública para proteger interesses coletivos.

2. Impossibilidade de o juiz substituir a Administração Pública determinando que obras de infra-estrutura sejam realizadas em conjunto habitacional. Do mesmo modo, que desfaça construções já realizadas para atender projetos de proteção ao parcelamento do solo urbano.

3. Ao Poder Executivo cabe a conveniência e oportunidade de realizar os atos físicos de administração (construção de conjuntos habitacionais etc.). $\mathrm{O}$ Judiciário não pode, sob o argumento de que está protegendo os direitos coletivos, ordenar que tais realizações sejam consumadas.

4. As obrigações de fazer permitidas pela ação civil pública não têm força de quebrar a harmonia e independência dos Poderes.

5. O controle dos atos administrativos pelo Poder Judiciário está vinculado a perseguir a atuação do agente público no campo de obediência aos princípios da legalidade, da moralidade, da eficiência, da impessoalidade, da finalidade e, em algumas situações, o controle do mérito.

6. As atividades de realização dos fatos concretos pela administração depende de dotações orçamentárias prévias e do programa de prioridades estabelecidos pelo governante. Não pode o Poder Judiciário, portanto, determinar as obras que deve edificar, mesmo que seja para proteger o meio ambiente."

Diante dessas decisões, nos parece oportuno examinar a extensão do poder discricionário à luz do sistema jurídico brasileiro e, especialmente, diante da necessidade de outorgar eficácia ao art. 225 da Constituição, o qual, ao mesmo tempo em que 
reconhece um direito fundamental, também impõe um dever ao Poder Público, que vem traduzido em diversas políticas de atuação pública que exercem função de garantia de proteção ambiental. ${ }^{4}$

Para tanto, cumpre avaliar as possibilidades de ingerência do Poder Judiciário na dita seara da discricionariedade administrativa para verificar, nos casos de omissão do Poder Público, a admissibilidade de intervenção do Poder Judiciário a fim de fazer valer as normas protetoras do meio ambiente.

\section{O DIREITO AO MEIO AMBIENTE EQUILIBRADO}

O direito ao meio ambiente ecologicamente equilibrado é um direito fundamental ${ }^{5}$ insculpido no Princípio $1^{\circ}$ da Declaração de Estocolmo, de $1972,{ }^{6}$ e reiterado no Princípio $1^{\circ}$ da Declaração do Rio, proferida na Conferência das Nações Unidas sobre Meio Ambiente e Desenvolvimento, ${ }^{7}$ que se situa dentre os direitos

$4 \mathrm{O} \S 1^{\circ}$ do art. 225 refere que "para assegurar a efetividade do direito ao meio ambiente ecologicamente equilibrado, incumbe ao Poder Público:

I - preservar e restaurar os processos ecológicos essenciais e prover o manejo ecológico das espécies e ecossistemas;

II - preservar a diversidade e a integridade do patrimônio genético do País e fiscalizar as entidades dedicadas à pesquisa e manipulação de material genético;

III - definir, em todas as unidades da Federação, espaços territoriais e seus componentes a serem especialmente protegidos, sendo a alteração e a supressão permitidas somente através de lei, vedada qualquer utilização que comprometa a integridade dos atributos que justifiquem sua proteção;

IV - exigir, na forma da lei, para instalação de obra ou atividade potencialmente causadora de significativa degradação ao meio ambiente, estudo prévio de impacto ambiental, a qual se dará publicidade;

V - controlar a produção, a comercialização e o emprego de técnicas, métodos e substâncias que comportem risco para a vida, a qualidade de vida e o meio ambiente;

VI - promover a educação ambiental em todos os níveis de ensino e a conscientização pública para a preservação do meio ambiente;

VII - proteger a fauna e a flora, vedadas, na forma da lei, as práticas que coloquem em risco sua função ecológica, provoquem a extinção das espécies ou submetam os animais a crueldade".

5 O termo "direito fundamental" aplica-se àqueles direitos do ser humano reconhecidos e positivados na esfera do direito constitucional positivo de determinado Estado, conforme entendimento de INGO SARLET (in A eficácia dos direitos fundamentais, $1^{\mathrm{a}}$ ed., Livraria do Advogado, 1998, p. 31). No mesmo sentido: PEREZ LUÑO, segundo o qual os direitos fundamentais "constituem o conjunto de direitos e liberdades institucionalmente reconhecidos e garantidos pelo direito positivo de determinado Estado, tratando-se, portanto, de direitos delimitados espacial e temporalmente, cuja denominação se deve ao seu caráter básico e fundamentador do sistema jurídico do Estado de Direito" (Los derechos fundamentales, p. 46-7, apud SARLET, ob. cit., p. 32).

6 Princípio $1^{\circ}$, da Declaração de Estocolmo: "O homem tem o direito fundamental à liberdade, à igualdade e ao desfrute de condições de vida adequadas em um meio cuja qualidade lhe permita levar uma vida digna e gozar de bem-estar e tem a solene obrigação de proteger e melhorar esse meio para as gerações presentes e futuras".

7 Princípio $1^{\circ}$, da Declaração do Rio: "Os seres humanos constituem o centro das preocupações relacionadas com o desenvolvimento sustentável. Têm direito a uma vida saudável e produtiva em harmonia com o meio ambiente". 
fundamentais de terceira geração, também denominados direitos de fraternidade ou de solidariedade, os quais trazem como nota distintiva o fato de se desprenderem, em princípio, da figura do homem-indivíduo como seu titular, destinando-se à proteção de grupos humanos (família, povo, nação), e caracterizando-se, conseqüentemente, como direitos de titularidade difusa ou coletiva. ${ }^{8}$ Sob outro enfoque, os direitos da terceira geração têm por destinatário precípuo o "gênero humano mesmo, num momento expressivo de sua afirmação como valor supremo em termos de existencialidade concreta". ${ }^{9}$

O surgimento do direito ao meio ambiente e os demais direitos de terceira geração são explicados por BOBBIO como tendo sido "uma passagem da consideração do indivíduo uti singulus, que foi o primeiro sujeito ao qual se atribuíram direitos naturais (ou morais) - em outras palavras, da 'pessoa' -, para sujeitos diferentes do indivíduo, como a família, as minorias étnicas e religiosas, toda a humanidade em seu conjunto (como no atual debate, entre filósofos da moral, sobre o direito dos pósteros à sobrevivência); e, além dos indivíduos humanos considerados singularmente ou nas diversas comunidades reais ou ideais que os representam, até mesmo para sujeitos diferentes dos homens, como os animais". ${ }^{10}$

O reconhecimento do direito ao meio ambiente equilibrado pela Declaração de Estocolmo ampliou, desta forma, o conceito de direitos humanos para abranger o direito de viver num ambiente sadio. ${ }^{11}$ Este direito, reivindicado pelos movimentos ecológicos, tornou-se um dos mais importantes direitos fundamentais da pessoa humana, pois, com a proteção do meio ambiente, resta salvaguardada não apenas a vida nas suas várias dimensões (individual, coletiva e até das futuras gerações), mas "as próprias bases da vida, o suporte planetário que viabiliza a existência da integralidade dos seres vivos. ${ }^{12}$ DARLAN RODRIGUES BITTENCOURT e RICARDO KOCHINSKI MARCONDES lecionam que "o reconhecimento do direito do homem ao meio ambiente harmônico e

8 SARLET, I. Obra citada, p. 50.

9 BONAVIDES, Paulo. Curso de direito constitucional, p. 523.

10 BOBBIO, Norberto. A era dos direitos. Rio de Janeiro: Campus, 1992, p. 69, apud BORGES, Roxana. Direito ambiental e teoria jurídica no final do século XX. In: VARELLA, Marcelo Dias; BORGES, Roxana (org.). O novo em direito ambiental. Belo Horizonte: Del Rey, 1998, p. 69.

11 CANÇADO TRINDADE refere que, no plano do direito internacional, cada vez mais freqüentemente tem sido reconhecida a íntima relação entre meio ambiente e direitos humanos, demonstrada pelo fato de que a degradação ambiental pode agravar as violações de direitos humanos e, por sua vez, as violações de direitos humanos podem conduzir à degradação ambiental ou dificultar a proteção do meio ambiente. Tais situações reforçam a necessidade de fortalecer ou desenvolver os direitos à alimentação, à água e à saúde (obra citada, p. 35-36).

12 BENJAMIN, Antônio Herman. Responsabilidade civil pelo dano ambiental. In: Revista de direito ambiental, v. 9, ano 3 jan.-mar., Ed. RT, 1998, p. 12. No mesmo sentido é a lição de ÉDIS MILARÉ, que vislumbra no reconhecimento do direito a um meio ambiente sadio uma extensão do direito à vida, quer sob o enfoque da própria existência física e saúde dos seres humanos, quer "quanto ao aspecto da dignidade desta existência - a qualidade de vida -, que faz com que valha a pena viver" (Princípios fundamentais do direito do ambiente. In: Revista dos Tribunais, v. 756, out. 1998, $87^{\circ}$ ano, p. 53). 
produtivo posicionou-o como bem jurídico fundamental à vida humana. Este status o insere ao lado do direito à vida, à igualdade, à liberdade, possuindo, contudo, um espectro bem mais amplo, de cunho social e histórico, e não meramente individual. Donde se extrai, como características desse direito, a sua indisponibilidade, oponibilidade a direitos individuais ou coletivos, bem como a sua imprescritibilidade e, ainda, a impossibilidade de haver direito adquirido sobre ou contra o meio ambiente". ${ }^{13}$

Com inspiração na Carta Portuguesa, a Constituição brasileira de 1988 consagrou o direito ao meio ambiente ecologicamente equilibrado como direito fundamental da pessoa humana (art. 225), ${ }^{14-15}$ traduzindo uma nova projeção do direito à vida, na medida em que esse direito abrange a manutenção daquelas condições ambientais que são suportes da própria vida. ${ }^{16}$ INGO SARLET adverte que, apesar de o direito ao meio ambiente equilibrado não se incluir no catálogo dos direitos fundamentais do art. $5^{\circ}$, da Constituição Federal de 1988, trata-se de um direito fundamental, definido "como típico direito difuso, inobstante também tenha por objetivo o resguardo de uma existência digna do ser humano, na sua dimensão individual e social". ${ }^{17}$

Nessas condições, o art. 225 correlaciona-se estreitamente com outros valores fundamentais consagrados pela Carta Magna, como a dignidade da pessoa humana, a liberdade, a igualdade e a justiça (Preâmbulo, arts. $1^{\circ}$ e $5^{\circ}$ ); bem como com os objetivos fundamentais de construir uma sociedade livre, justa e solidária; de garantir o desenvolvimento nacional; erradicar a pobreza e a marginalização e reduzir as desigualdades sociais e regionais; promover o bem de todos (art. $3^{\circ}$ ); e ainda com os direitos individuais e coletivos, tais como o direito à vida, à função social da propriedade e ação popular (art. $5^{\circ}$, caput, e incisos XXIII e LXXIII). ${ }^{18}$

CANÇADO TRINDADE refere que, "em sua dimensão ampla e própria, o direito fundamental à vida compreende o direito de todo ser humano de não ser privado de sua

13 BITTENCOURT, Darlan Rodrigues; MARCONDES, Ricardo Kochinski. Lineamentos da responsabilidade civil ambiental. Revista dos Tribunais, v. 740, 86 ${ }^{\circ}$ ano, Ed. RT, p. 69, jun. 1997.

14 “Art. 225. Todos têm direito ao meio ambiente ecologicamente equilibrado, bem de uso comum do povo e essencial à sadia qualidade de vida, impondo-se ao Poder Público e à coletividade o dever de defendê-lo e preservá-lo para as presentes e futuras gerações."

15 ANTÔNIO HERMAN BEJAMIN entende que a Constituição Federal de 1988 elevou o direito ao meio ambiente à categoria de direito fundamental do homem, ao caracterizar o equilíbrio ecológico como bem essencial à sadia qualidade de vida (In: Responsabilidade civil pelo dano ambiental ..., ob. cit., p. 12).

16 No sentido de que o art. 225 da Constituição Federal de 1988 acolhe um direito fundamental: ANTUNES, Paulo de Bessa. Direito ambiental. Rio de Janeiro: Lumen Juris, 1996, p. 22; SILVA, José Afonso. Direito ambiental constitucional. 2. ed., 2a tir., São Paulo: Malheiros, 1997, p. 36.

17 SARLET, I. Obra citada, p. 123. Do mesmo sentir compartilha LUIZ RÉGIS PRADO, segundo o qual o direito ao meio ambiente ecologicamente equilibrado foi erigido a direito fundamental de cunho social dentro de uma perspectiva de melhoria da qualidade de vida e de bem-estar social (A tutela constitucional do ambiente no Brasil, ob. cit., p. 85).

18 LUIZ RÉGIS PRADO, ob. cit., p. 85. 
vida (direito à vida) e o direito de todo ser humano de dispor dos meios apropriados de subsistência e de um padrão de vida decente (preservação da vida, direito de viver)". ${ }^{19}$ Nesta perspectiva, "o direito a um meio ambiente sadio e o direito à paz configuram-se como extensões ou corolários do direito à vida. O caráter fundamental do direito à vida torna inadequados enfoques restritos do mesmo em nossos dias; sob o direito à vida, em seu sentido próprio e moderno, não só se mantém a proteção contra qualquer privação arbitrária da vida, mas além disso encontram-se os Estados no dever de buscar diretrizes destinadas a assegurar o acesso aos meios de sobrevivência a todos os indivíduos e todos os povos. Neste propósito, têm os Estados a obrigação de evitar riscos ambientais sérios à vida, e de pôr em funcionamento sistemas de monitoramento e alerta imediato para detectar riscos ambientais sérios e sistemas de ação urgente para lidar com tais ameaças". 20

O fato de a Constituição de 1988 haver garantido o direito ao meio ambiente sadio confirma esta projeção, pois resta salvaguardado o direito à vida sob dois aspectos, a saber, a existência física e saúde dos seres humanos, e a dignidade desta existência, a qualidade de vida que faz com que valha a pena viver. $O$ direito a um meio ambiente sadio, desta forma, compreende e amplia o direito à saúde e o direito a um padrão de vida adequado.

Como norma de caráter teleológico, o art. 225 impõe uma orientação de todo o ordenamento infraconstitucional, ficando patenteado o reconhecimento do direito-dever ao meio ambiente ecologicamente equilibrado, a obrigação dos poderes públicos e da coletividade de defendê-lo e de preservá-lo e a previsão de sanções para as condutas ou atividades lesivas. A preservação do ambiente passa a ser, portanto, a base em que se assenta a política econômica e social, ${ }^{21}$ pois, uma vez inseridas em um sistema constitucional, as normas relativas a outros ramos jurídicos, que se relacionam com o amplo conceito de meio ambiente, não podem ser aplicadas sem levar em conta as normas ambientais que impregnam a ideologia constitucional. ${ }^{22}$

\section{A EFICÁCIA DO DIREITO AO MEIO AMBIENTE COMO UM DIREITO FUNDAMENTAL E A CONCEPÇÃO DE UM MÍNIMO VITAL EM TERMOS DE QUALIDADE AMBIENTAL}

A Constituição Federal de 1988, no seu art. $5^{\circ}, \S 1^{\circ}$, outorgou especial significado aos direitos fundamentais, conferindo-lhes eficácia vinculante imediata, gravando-os com a cláusula de imutabilidade ou garantia de eternidade.

19 CANÇADO TRINDADE, ob. cit., p. 73.

20 Idem, p. 75.

21 Veja-se que o art. 170, inciso VI, da Constituição Federal de 1988, prevê que "a ordem econômica, fundada na valorização do trabalho humano e na livre iniciativa, tem por fim assegurar a todos existência digna, conforme os ditames da justiça social, observado o princípio da defesa do meio ambiente".

22 FARIAS, Paulo José Leite. Competência federativa e proteção ambiental. Porto Alegre: Sérgio Antônio Fabris, 1999, p. 226. O autor refere que a ideologia adotada pela Constituição Federal de 1988 permite que se fale em Estado de Direito Ambiental, o que impregna todas as normas que se relacionam com o vasto leque do domínio normativo da expressão "meio ambiente". 
Interpretando esse dispositivo, INGO SARLET refere que, embora sua situação topográfica possa sugerir que sua aplicabilidade limite-se aos direitos fundamentais reconhecidos no art. $5^{\circ}$, assim não ocorre, estendendo-se a norma a todos os direitos fundamentais constantes da Carta Constitucional, já que a nossa Constituição não estabeleceu distinções hierárquicas entre os direitos de liberdade e os direitos sociais, encontrando-se todas as categorias de direitos fundamentais sujeitas, em princípio, ao mesmo regime jurídico. Por conseguinte, "há como sustentar, a exemplo do que tem ocorrido na doutrina, a aplicabilidade imediata (por força do art. $5^{\circ}, \S 1^{\circ}$, de nossa Lei Fundamental) de todos os direitos fundamentais constantes do Catálogo (arts. $5^{\circ}$ a 17), bem como dos localizados em outras partes do texto constitucional e nos tratados internacionais. Aliás, a extensão do regime material da aplicabilidade imediata aos direitos fora do catálogo não encontra qualquer óbice no texto constitucional, harmonizando, para além disso, com a concepção materialmente aberta dos direitos fundamentais consagrada, entre nós, no art. $5^{\circ}, \S 2^{\circ}$, da CF". ${ }^{23}$

SARLET também aduz, acertadamente, que a norma contida no art. $5^{\circ}, \S 1^{\circ}$, impõe aos órgãos estatais a tarefa de maximizar a eficácia dos direitos fundamentais; e, com fulcro na lição de CANOTILHO, ressalta o caráter dirigente e vinculante desta norma, "no sentido de que esta, além do objetivo de assegurar a força vinculante dos direitos e garantias de cunho fundamental, ou seja, objetiva tornar tais direitos prerrogativas diretamente aplicáveis pelos Poderes Legislativo, Executivo e Judiciário, (...) investe os poderes públicos na atribuição constitucional de promover as condições para que os direitos e garantias fundamentais sejam reais e efetivos". ${ }^{24}$

No que diz respeito à aplicabilidade imediata do art. 225 , de sorte a se exigir do Poder Público prestações efetivas para a proteção do meio ambiente, há que se considerar, todavia, o limite da reserva do possível. É que não se pode cair no irrealismo de ignorar a dimensão economicamente relevante da incumbência do Poder Público de tutelar o meio ambiente, quando isto implica prestações específicas, tais como investimento em saneamento básico, pavimentação de ruas, implantações de estações de tratamento de esgoto etc. Tais medidas tornam-se inviáveis na falta de recursos econômicos, dependendo, em última análise, da conjuntura econômica.

A respeito do limite da reserva do possível, SARLET refere que a expressão abrange tanto a possibilidade quanto o poder de disposição por parte do destinatário da norma. Vale-se o eminente doutrinador de precedentes da Corte Constitucional Federal da Alemanha, no sentido "de que a prestação reclamada deve corresponder ao que o indivíduo pode razoavelmente exigir da sociedade, de tal sorte que, mesmo em dispondo o Estado de recursos e tendo o poder de disposição, não se pode falar em uma obrigação de prestar algo que não se mantenha nos limites do razoável". ${ }^{25}$

Neste contexto, SARLET refere o entendimento de VIEIRA DE ANDRADE, segundo o qual, "por estar em causa uma verdadeira opção quanto à afetação material

23 SARLET, ob. cit., p. 236.

24 Idem, p. 243.

25 Idem, p. 261. 
dos recursos, também deve ser tomada uma decisão sobre a aplicação destes, que, por sua vez, depende da conjuntura socioeconômica global, partindo-se, neste sentido, da premissa de que a Constituição não oferece, ela mesma, os critérios para esta decisão, deixando-a ao encargo dos órgãos políticos (de modo especial o legislador) competentes para a definição das linhas gerais das políticas na esfera socioeconômica". ${ }^{26}$

Nos parece que a saída para o impasse que pode decorrer da dependência de uma conjuntura socioeconômica é o reconhecimento do direito ao mínimo vital para lograr uma existência digna, ou seja, de um direito, por parte da sociedade, à obtenção de prestações públicas de condições mínimas de subsistência na seara ambiental, as quais, acaso desatendidas, venham a criar riscos graves para a vida e a saúde da população, ou riscos de dano ambiental irreparável. Como exemplos, poder-se-ia citar o problema de deposição de lixo urbano a céu aberto, de sorte a criar perigos para a saúde da população circundante e riscos ambientais de contaminação das águas, do solo e da vegetação. Ou a contaminação de corpos hídricos que sejam vitais para o abastecimento público; ou, ainda, a contaminação do ar com poluentes nefastos para a saúde humana.

Considerando-se que o direito ao meio ambiente equilibrado é pressuposto para a vida e para a saúde, não há como negar o seu vínculo com o princípio da dignidade da pessoa humana e, nas palavras de SARLET, "se atentarmos contra a dignidade, estaremos, na verdade, atentando contra a própria humanidade do indivíduo". SARLET ainda pondera que "ao Estado não apenas é vedada a possibilidade de tirar a vida (daí, por exemplo, a proibição da pena de morte), mas também que a ele se impõe o dever de proteger ativamente a vida humana, já que esta constitui a própria razão de ser do Estado, além de pressuposto para o exercício de qualquer direito (fundamental, ou não)". 27

CANOTILHO corrobora este entendimento ao afirmar que "o Estado, os poderes públicos, o legislador, estão vinculados a proteger o direito à vida, no domínio das prestações existenciais mínimas, escolhendo um meio (ou diversos meios) que tornem efetivo este direito, e, no caso de só existir um meio de dar efetividade prática, devem escolher precisamente esse meio". ${ }^{28}$

É claro que se pode argumentar a dificuldade de se determinar qual o conteúdo deste padrão mínimo em proteção ambiental a ser assegurada mediante prestações materiais por parte do Estado, ressaltando-se a inviabilidade de formular-se um padrão genérico. Por conseguinte, será indispensável uma análise casuística, à luz das circunstâncias do caso concreto. Um critério é o próprio princípio da dignidade da pessoa humana, que vem a assumir, portanto, função demarcatória a traçar o conteúdo do padrão mínimo.

26 ANDRADE, Vieira. Os direitos fundamentais, p. 200, apud SARLET, ob. cit., p. 261.

27 SARLET, ob. cit., p. 318/319.

28 CANOTILHO, J. J. Gomes. Tomemos a sério os direitos econômicos, sociais e culturais, apud SARLET, ob. cit., p. 299. 
Daí que, em alguns casos, será imperiosa a intervenção do Poder Público, a fim de evitar o agravamento de riscos ambientais graves à saúde e à vida humana, como nas hipóteses de tratamento e destinação final dos resíduos sólidos urbanos, de sorte a evitar a contaminação ambiental e a proliferação de vetores, bem como na hipótese de tratamento de esgotos domésticos, cuja exposição a céu aberto contribui imensamente para as mais diversas doenças.

\section{A DISCRICIONARIEDADE ADMINISTRATIVA}

Poder discricionário, consoante lição de HELY LOPES MEIRELLES, “é o que o Direito concede à Administração, de modo explícito ou implícito, para a prática de atos administrativos com liberdade na escolha de sua conveniência, oportunidade e conteúdo". ${ }^{29}$ Implica na faculdade que adquire a Administração para assegurar de forma eficaz o interesse público, objetivo principal a que se propõe o Poder Público.

Para CELSO ANTÔNIO BANDEIRA DE MELLO, "discricionariedade é a margem de liberdade que remanesça ao administrador para eleger, segundo critérios consistentes de razoabilidade, um, dentre pelo menos dois comportamentos cabíveis, perante cada caso concreto, a fim de cumprir o dever de adotar a solução mais adequada à satisfação da finalidade legal, quando, por força da fluidez das expressões da lei ou da liberdade conferida no mandamento, dela não se possa extrair, objetivamente, uma solução unívoca para a situação vertente". ${ }^{30}$

Vale, ainda, colacionar FIORINI, segundo o qual o poder discricionário "não é um instrumento legal que se concede ao administrador para fazer o que imponha o seu capricho; nem tampouco para criar normas de caráter legislativo; menos ainda para que intervenha ante uma contenda normativa, como acontece com a jurisdição. $\dot{E}$, unicamente, uma autorização limitada a um fim determinado, para que o Poder Público aprecie as condições presentes quando administre o interesse social especificado pela norma legislativa. É uma forma de atuar da Administração Pública para poder realizar uma reta administração dos diversificados interesses da coletividade". ${ }^{31}$

Por conseguinte, o Poder discricionário tampouco constitui uma faculdade natural ou originária do Poder Público, ${ }^{32}$ apresentando-se, nas palavras de QUEIRÓ, “como uma certa margem de liberdade, concedida deliberadamente pelo legislador à Administração, a fim de que esta escolha o comportamento mais adequado para a realização de um determinado fim público". ${ }^{33}$

29 MEIRELLES, Hely Lopes. Direito administrativo brasileiro. 21. ed. São Paulo: Malheiros, 1996, p. 102.

30 MELlO, Celso Antônio Bandeira de. Discricionariedade e controle judicial. 2. ed. São Paulo: Malheiros, 1998, p. 09.

31 FIORINI, Bartolomé. La discrecionalidad en la administración pública. Buenos Aires, 1948, p. 38, in MEIRELLES, H., ob. cit., p. 152; grifou-se.

32 QUEIRÓ, Afonso Rodrigues. Os limites do poder discricionário das autoridades administrativas. In Estudos de Direito Administrativo, I, Atlântida, Ed. Coimbra, 1967, p. 07.

33 Idem, p. 08. No mesmo sentido, CELSO ANTÔNIO BANDEIRA DE MELLO leciona que o poder discricionário só pode existir como um poder "intralegal" e estritamente dependente da lei, estritamente subordinado à lei (ob. cit., p. 13). 
Este fim é a concretização do interesse público que o órgão da Administração procura atingir com a sua conduta. ${ }^{34}$ Nesta medida, há uma vinculação do Administrador à lei e à observância do interesse público, situação esta que confere um conceito dinâmico de legalidade, para além dos critérios meramente formais, na medida em que a atividade administrativa seja ao mesmo tempo útil, conveniente e oportuna, bem como disposta ao cumprimento da verdadeira finalidade querida pela lei, qual seja, o interesse público. Refere que "un nuevo concepto de la legalidad o legitimidad administrativa se va abriendo aí paso, mucho más enriquecido que el anterior por múltiples vivencias actuales, que hacen a la obtención de aquel derecho a ser felices de que hemos hablado precedentemente". ${ }^{35}$

Por seu turno, o princípio do interesse público está relacionado à concepção de bem-estar, destacando ESCOLA que tal interesse não se resume à soma de uma maioria de interesses individuais coincidentes, pessoais, diretos, atuais ou eventuais, mas significa o resultado de um interesse emergente da existência da vida em comunidade, na qual a maioria dos indivíduos reconhece, também, um interesse próprio e direto. ${ }^{36}$

JUAREZ FREITAS aborda o princípio do interesse público como correlato ao princípio da dignidade da pessoa humana, destacando-o como o mais importante dentre todos os princípios constitucionais que versam sobre a Administração Pública, com o que ESCOLA parece concordar, já que preceitua que tal princípio é o sustentáculo de todo o Direito Administrativo.$^{37}$ Refere que "a especificidade do princípio do interesse público está em prescrever que, em caso de colisão, deve preponderar a vontade geral legítima sobre a vontade egoisticamente articulada". ${ }^{38}$ Esse princípio representa a indução legítima de que "se subordinem as condutas e os bens particulares ao interesse geral digno desse nome, o qual também haverá de se configurar afinado com o interesse lícito de cada cidadão". ${ }^{39}$

ESCOLA aponta que o interesse público constitui um limite para a atividade administrativa, discricionária ou não, já que a administração pública sempre tem que

34 CAETANO, Marcello. Manual de direito administrativo. 10. ed. Almedina: Coimbra, v. I, 1991, p. 484. A respeito do fim do ato administrativo, CAETANO revela que o tema ganha importância justamente na seara da discricionariedade, já que, nos atos vinculados, a lei cuida de traçar rigorosamente a via a seguir pelos seus executores, não permitindo margem de autonomia.

35 ESCOLA, Héctor Jorge. El interés público como fundamento del derecho administrativo. Buenos Aires: Ediciones Depalma, 1989, p. 29.

36 Idem, p. 31.

37 ESCOLA define o Direito Administrativo como "el complejo de principios y normas de derecho público interno que regula la organización y el comportamiento de la administración pública, directa e indirecta, las relaciones de ésta con los administrados y de sus distintos órganos y entes entre sí, a fin de que se logren e satisfagan las finalidades de interés público hacia las que debe tender toda la actividad de la administración" (ob. cit., p. 32).

38 FREITAS, Juarez. O controle dos atos administrativos e os princípios fundamentais. São Paulo: Malheiros, 1997, p. 54.

39 Idem, p. 55 
atuar com observância das exigências e necessidades do interesse público..$^{40}$ No mesmo sentido, QUEIRÓ, ao abordar os limites internos ao poder discricionário, rechaça as condutas arbitrárias e as escolhas caprichosas, fundadas em interesses individuais, preceituando que o administrador obre com "honestidade" na escolha da medida mais adequada, o que ocorre quando se almeja o interesse público. Diz que "as autoridades administrativas só exercem legalmente o seu poder discricionário quando façam a escolha da medida a tomar em dado caso, orientando-se pelo propósito de servirem da melhor maneira o interesse público específico a realizar, e procedam de acordo com a escolha assim efetuada. A ação deve harmonizar-se com uma escolha honestamente feita". E afirma o autor que a escolha é feita honestamente "se e enquanto a autoridade administrativa tiver em vista, ao decidir-se entre os comportamentos à sua disposição, o interesse público específico a realizar. Este interesse deverá, por assim dizer, ser a luz que ilumina a autoridade administrativa, deverá ser o ponto cardial por onde ela se orienta" ${ }^{41}$ No caso de o administrador escolher outra opção que - embora lícita - não contemple o interesse público, QUEIRÓ entende que haverá ilegalidade.

Como decorrência desta necessidade de busca de realização do interesse público como conseqüência da realização da dignidade da pessoa humana, a concessão de liberdade ao administrador diz exclusivamente com a apreciação de certos pressupostos, com a conveniência de agir ou de abster-se, com o momento de agir, com o objeto, com as formalidades e com a forma do ato. Isto porque, segundo MARCELLO CAETANO, o legislador entende que se entra numa zona que pertence preferentemente ou até exclusivamente a uma função não jurídica, mas sim técnica. ${ }^{42}$

Ademais, há que se considerar a impossibilidade de a lei esgotar todos os atos que a prática administrativa demanda. Sob esta ótica, o fundamento da discricionariedade parte da consideração de que apenas o administrador teria condições de apreciar adequadamente os motivos ocorrentes de oportunidade e conveniência da prática de certos atos. Por isso, atribui-se-lhe o encargo de eleger a medida ou procedimento mais idôneo à prossecução de uma finalidade pública, cuja realização é reputada necessária pelo legislador. Ocorre, então, "uma deliberada abdicação do poder planificador ou

40 ESCOLA, ob. cit., p. 41.

41 QUEIRÓ, ob. cit., p. 17/18. A respeito dos limites do poder discricionário, QUEIRÓ, sob a ótica do direito português, distingue os limites externos dos limites internos. Dentre os limites externos estariam: 1) as normas de competência subjetiva ou orgânica, já que a competência subjetiva é sempre vinculativamente fixada pelo legislador, não se admitindo aos órgãos da Administração eleger ou fixar discricionariamente a sua competência subjetiva; 2) as normas de competência material, quais sejam aquelas que delimitam as atribuições dos diversos entes públicos; 3) as normas de conteúdo, assim entendidas aquelas que, por qualquer forma, enunciam o quadro ou série dos meios jurídicos, procedimentos, medidas ou disposições entre as quais a autoridade competente há de fazer a sua escolha discricionária; 4) as normas enunciadoras de motivos antecedentes, quais sejam, as circunstâncias-defato, expressas na lei, que justificam o atuar administrativo.

42 CAETANO, ob. cit., p. 214. Conforme o autor, o poder é vinculado na medida em que o seu exercício está regulado por lei; e será discricionário quando o seu exercício fica entregue ao critério do respectivo titular, deixando-lhe liberdade de escolha do procedimento a adotar em cada caso como mais ajustado à realização do interesse público protegido pela norma que o confere. 
ordenador que ao legislador compete em relação à atividade executiva ou administrativa, de um intencional eclipse da vontade da lei, destinado a dar lugar à vontade da Administração, no pressuposto de que esta está freqüentemente em melhores condições do que o legislador para, dentro de certos limites, escolher a medida mais eficiente, com vista à realização do interesse público que se destina justamente a prosseguir". ${ }^{43}$

No que concerne à natureza do poder discricionário, ANDRÉ GONÇALVES PEREIRA apresenta três correntes doutrinárias que procuram explicar onde reside a discricionariedade: "O primeiro setor doutrinário vê na discricionariedade uma liberdade de escolha do agente entre vários comportamentos possíveis: a lei indicaria ao agente $\mathrm{o}$ fim a prosseguir mas deixar-lhe-ia a determinação dos meios e das circunstâncias. $\mathrm{O}$ segundo grupo pretende que a discricionariedade é uma operação intelectual por parte do agente: a norma jurídica emprega por vezes conceitos vagos, imprecisos ou suscetíveis de vários sentidos e compete ao agente completar a norma, precisar-lhe o sentido e obter assim a diretiva para o caso concreto (...). Por fim, a última corrente considera que o cerne da discricionariedade é a remissão do agente para normas extrajurídicas que podem ser técnicas, científicas ou ainda normas de boa administração. O agente deveria sempre preencher o vazio da norma jurídica com a referência a estas normas". ${ }^{44}$

ANDRÉ GONÇALVES PEREIRA, no que vem acompanhado por MARCELLO CAETANO,${ }^{45}$ inclina-se pela primeira corrente, rejeitando as demais sob o argumento de que a segunda trata de interpretar conceitos indeterminados e a terceira não define o caráter jurídico do poder discricionário, limitando-se a afirmar que o seu exercício fica condicionado a normas não jurídicas.

CELSO ANTÔNIO, por seu turno, entende que os conceitos indeterminados são causas normativas da discricionariedade, e não mera questão interpretativa. ${ }^{46}$ Por conseguinte, expressa que a discricionariedade pode decorrer: 1) da hipótese da norma, "ou seja, do modo impreciso com que a lei haja descrito a situação fática (motivo), isto

43 QUEIRÓ, ob. cit., p. 10.

44 PEREIRA, André Gonçalves. Erro e ilegalidade no ato administrativo, 1962, p. 216. O autor entende que não há liberdade da interpretação da norma, sendo que a discricionariedade começa onde acaba a interpretação. Sustenta o descabimento de reduzir a discricionariedade à formulação de um juízo. Quanto à remissão para regras científicas ou técnica, ANDRÉ G. PEREIRA refere que esta situação aplica-se apenas à discricionariedade técnica, que não se confunde com a discricionariedade administrativa propriamente dita. Salienta que, em algumas situações, a fim de atingir o interesse público, poderá a Administração deixar de seguir técnicas reconhecidas pela boa administração.

45 CAETANO, ob. cit., p. 215

46 CELSO ANTÔNIO entende que os conceitos fluidos dão azo à discricionariedade, na medida em que possibilitam a convivência de intelecções diferentes, todas corretas conquanto que razoáveis. Refere que, "se em determinada situação real o administrador reputar, em entendimento razoável (isto é, comportado pela situação, ainda que outra opinião divergente fosse igualmente sustentável), que se lhe aplica o conceito normativo vago e agir nesta conformidade, não se poderá dizer que violou a lei, que transgrediu o direito (...). Em assim sendo, evidentemente, terá procedido dentro de uma liberdade intelectiva que, in concreto, o direito lhe facultava" (p. 23). 
é, o acontecimento do mundo empírico que fará deflagrar o comando da norma, ou da omissão em descrevê-lo; 2) do comando da norma, quando nele se houver aberto, para o agente público, alternativas de conduta, seja a) quanto a expedir ou não expedir $o$ ato, seja b) por caber-lhe apreciar a oportunidade adequada para tanto, seja c) por lhe conferir liberdade quanto à forma jurídica que revestirá o ato, seja d) por lhe haver sido atribuída competência para resolver sobre qual será a medida mais satisfatória perante as circunstâncias", ${ }^{47}$ e 3) da finalidade da norma, posto que a finalidade aponta para valores e as palavras ao se reportarem a um conceito de valor estão se reportando a conceitos plurissignificativos, isto é, vagos, imprecisos, como são exemplos os termos "moralidade pública", "higiene pública", "interesse público".48

Esclarece CAETANO que, em regra, o órgão administrativo tem poderes vinculados quanto a alguns dos elementos do ato administrativo e discricionários quanto a outros. Por isso não se pode rigorosamente falar-se em atos discricionários: "não há atos discricionários, existem apenas atos praticados no exercício de poderes discricionários cumulativamente com poderes vinculados". ${ }^{49}$ Refere, ainda, que o fim do ato é a vinculação característica da discricionariedade, elucidando que "a discricionariedade não exclui absolutamente uma vinculação: discricionário significa livre dentro de limites permitidos pela realização de certo fim. O fim é um vínculo: corresponde a um requisito de validade cuja falta produz a invalidade do ato administrativo". ${ }^{0}$

Essa vinculação à finalidade legal já permite concluir que a discricionariedade não se confunde com arbitrariedade, ${ }^{51}$ posto que representa liberdade de ação administrativa dentro dos limites autorizados pela lei, ${ }^{52}$ mais aproximando-se, isto sim, do conceito de "dever" de atingir determinada finalidade pública. ${ }^{53}$ Neste sentido,

47 MELLO, ob. cit., p. 17 a 19.

48 Idem, p. 19. Quanto a esta causa normativa geradora de discricionariedade, verifica-se divergência entre MELLO e CAETANO. CELSO ANTÔNIO esclarece que, "embora se deva considerar que as causas determinantes da discricionariedade irão residir num dos três mencionados fatores (hipótese, mandamento ou finalidade da norma), não é neles que a discrição se expressa. A discrição administrativa vai se expressar em um único elemento que é o conteúdo do ato, porque é na ocasião em que se pratica $\mathrm{o}$ ato, elegendo o ato tal ou o ato qual, uma vez decidido qual o instante de praticá-lo (quando há discrição também quanto a isto), é na providência adotada que realmente se traduz a discrição" (p. 21).

49 CAETANO, ob. cit., p. 485.

50 Idem, p. 486.

51 Idem, p. 103.

$52 \mathrm{O}$ administrador, para a prática de ato discricionário, deverá ter competência legal, obedecendo à forma prescrita em lei e deverá atender à finalidade legal de todo ato administrativo, qual seja o interesse público.

53 CELSO ANTÔNIO entende que "na Ciência do Direito Administrativo, erradamente e até de modo paradoxal, quer-se articular os institutos do direito administrativo - inobstante ramo do direito público - em torno da idéia de poder, quando o correto seria articulá-lo em torno da idéia de dever, de finalidade a ser cumprida. Em face da finalidade, alguém - a Administração Pública - está posta numa situação que os italianos chamam de doverosità, isto é, sujeição a esse dever de atingir esta finalidade. Como não há outro meio para se atingir esta finalidade, para obter-se o cumprimento deste dever, senão 
LÚCIA VALLE DE FIGUEIREDO afirma consistir a discricionariedade numa "competência-dever", atribuída ao administrador para agir no caso concreto, de acordo com o critério da razoabilidade geral. ${ }^{54}$

Também a vinculação à finalidade é destacada por CELSO ANTÔNIO, para quem ocorre verdadeira sujeição da Administração a determinado fim, emergindo a noção de dever discricionário de atingir a finalidade. O poder surge, neste contexto, "como mero instrumento impostergável para que se cumpra o dever (...). Assim, o dever assinalado pela lei, a finalidade nela estampada, propõem-se, para qualquer agente público, como um imã, como uma força atrativa inexorável do ponto de vista jurídico". ${ }^{55}$

Havendo um dever de atingir a finalidade pública prescrita em lei, que é a realização do interesse público, pode-se, desde logo, apontar que a discricionariedade implicará liberdade exclusivamente quanto à escolha das medidas para o alcance desta finalidade. E, a respeito deste tema, a doutrina vem destacando que a existência de várias soluções válidas é a característica essencial da discricionariedade, e que permite distingui-la da interpretação da lei e da discricionariedade técnica, e da referência às regras de boa administração - já que todas levam apenas a uma solução objetivamente válida. ${ }^{56}$

Também JUAN IGARTUA SALAVERRÍA entende que a discricionariedade possui como característica a possibilidade de escolha entre opções, seja porque são plurais as conseqüências razoavelmente atribuídas a uma circunstância de fato, seja porque a faculdade que a letra da lei confere habilita uma margem mais ou menos ampla de liberdade, ou porque há um leque de instrumentos aptos para lograr a finalidade prescrita. Refere o autor que tais opções somente podem ser determinadas em um contexto concreto. ${ }^{57}$

No entanto, esta matéria não é pacífica. A doutrina diverge sobre se todas são igualmente justas e suscetíveis de escolha, ou se apenas uma delas é a que melhor alberga o interesse público, quando, então, se coloca em dúvida o próprio conceito de discricionariedade, já que, na prática, não haverá pluralidade de opções, mas apenas uma única escolha. ${ }^{58}$ A este respeito, FERNANDEZ refere que eleger a melhor solução

irrogar a alguém certo poder instrumental, ancilar ao cumprimento do dever, surge o poder, como mera decorrência, como mero instrumento impostergável para que se cumpra o dever. Mas é dever que comanda toda a lógica do Direito Público. Assim, o dever assinalado pela lei, a finalidade nela estampada, propõem-se, para qualquer agente público, como um imã, como uma força atrativa inexorável do ponto de vista jurídico" (p. 14).

54 FIGUEIREDO, Lúcia Valle. Curso de direito administrativo. 1. ed. São Paulo: Malheiros, p. 123.

55 MELLO, ob. cit., p. 15; grifou-se.

56 PEREIRA, ob. cit., p. 221.

57 SALAVERRÍA, Juan Igartua. Discrecionalidad técnica, motivación y control jurisdicional. Editorial Civitas: Madrid, 1998, p. 36.

58 SALAVERRÍA refere que não há discricionariedade quando a solução tomada era a única possível entre as circunstâncias de fato (recursos financeiros disponíveis etc.) (p. 38). 
é obrigatório para todo aquele que exerce uma função, isto é, um poder outorgado em consideração a interesses de terceiros. ${ }^{59}$

Esta discussão surge com intensidade no debate sobre a possibilidade de o Judiciário substituir a decisão discricionária por outra melhor e mais razoável diante do caso concreto. ${ }^{60}$ É que, se existe apenas uma decisão adequada - a mais razoável e atenta ao interesse público -, não haveria vontade discricionária.

Nesta linha, precisa é colocação de FERNÁNDEZ: “cuando las circunstancias del caso han reducido con toda evidencia la inicial pluralidad de soluciones teóricamente posibles a una sola, es decir, en los supuestos en que la doctrina alemana habla de reducción auf Null del poder discrecional es cuando nuestra jurisprudencia, empujada por la lógica imparable del derecho fundamental a la tutela efectiva, da el paso final e incluye en la Sentencia, junto al pronunciamiento anulatorio de la decisión recurrida, el de la condena a la Administración a dictar la única decisión que, dadas las concretas circunstancias del caso, resulta juridicamente posible" ${ }^{61}$

CELSO ANTÔNIO compartilha do entendimento de que a discricionariedade implica no dever de adotar a melhor solução, ao afirmar que a lei só pode pretender, tanto nos casos de vinculação, quanto nos casos de discrição, que a conduta do administrador atenda excelentemente, à perfeição, a finalidade que a animou. Afirma o autor que "a lei só quer aquele específico ato que venha a calhar à fiveleta para o atendimento do interesse público. Tanto faz que se trate de vinculação, quanto de discrição. O comando da norma sempre propõe isto e se uma norma é uma imposição, o administrador está, então, nos casos de discricionariedade, perante o dever jurídico de praticar, não qualquer ato dentre os comportados pela regra, mas, única e exclusivamente, aquele que atenda com absoluta perfeição à finalidade da lei" ${ }^{62}$

No caso de a conduta não atingir de modo preciso e excelente a finalidade legal, o administrador terá agido de forma contrária ao Direito, o ato será reputado inválido. Com isso, CELSO ANTÔNIO conclui que "discrição administrativa não pode significar campo de liberdade para o administrador, dentre as várias hipóteses abstratamente comportadas pela norma, eleja qualquer delas no caso concreto. Em última instância, o que se está dizendo é o seguinte: o âmbito de liberdade do administrador perante a norma não é o mesmo âmbito de liberdade que a norma lhe quer conferir perante o fato.

59 FERNANDEZ, ob. cit., p. 86.

60 SALAVERRÍA refere que o juízo de razoabilidade somente pode se dar à luz dos fatos concretos, posto que uma decisão a prima facie má em si mesma pode se revelar boa diante de outras ainda piores (ob. cit., p. 41).

61 FERNANDEZ, ob. cit., p. 208.

62 MELLO, ob. cit., p. 33. O autor expõe que a única razão lógica capaz de justificar a outorga de discrição reside em que não se considerou possível fixar, de antemão, qual seria o comportamento administrativo pretendido como imprescindível e reputado capaz de assegurar, em todos os casos, a única solução prestante para atender com perfeição ao interesse público que inspirou a norma. 
Está-se afirmando que a liberdade administrativa, que a discrição administrativa, é maior na norma de Direito do que perante a situação concreta". ${ }^{63}$

Todavia, CELSO ANTÔNIO reconhece a impossibilidade de eliminar o subjetivismo quanto à escolha da opção mais adequada, já que a aptidão humana para desvendar a solução que satisfaria idealmente a finalidade legal é limitada e finita; e invoca o conceito de razoabilidade para resolver o impasse: "a providência ideal em muitas situações é objetivamente incognoscível. Poder-se-á tão-somente saber que será uma que se contenha dentro de um número limitado de alternativas e que se apresente como razoável no caso concreto". ${ }^{64}$

SALAVERRÍA também se socorre da concepção de razoabilidade ao conceituar o poder discricionário: "hay un margen discrecional cuando sobre una cuestión aparecen varias soluciones razonables y es preciso elegir entre ellas. Por tanto, el margen discrecional no es algo dado a priori sino algo ganado (en la medida en que los contendientes son capaces de defender soluciones alternativas razonables)".${ }^{65} \mathrm{Em}$ virtude deste conceito é que o autor refere que o exercício da vontade discricionária pressupõe dois elementos: uma opção entre várias soluções realmente possíveis, a qual deve ser razoável em um marco sociocultural determinado.

\section{O CONTROLE JUDICIAL DA DISCRICIONARIEDADE PARA A PROTEÇÃO DO MEIO AMBIENTE}

O controle judicial dos atos discricionários passa pela discussão sobre os limites da atividade discricionária e sobre a possibilidade de eventual substituição da decisão administrativa discricionária pelo Poder Judiciário, no caso de omissão da Administração Pública ou quando esta escolhe uma medida manifestamente irrazoável.

A respeito dos limites, assiste razão a INGO SARLET, quando aponta como limite ao agir discricionário a vinculação dos órgãos administrativos aos direitos fundamentais, na medida em que atuam no interesse público, no sentido de serem guardiães e gestores da coletividade. ${ }^{66}$ Destaca que a não-observância deste postulado poderá levar à invalidação judicial dos atos administrativos contrários aos direitos fundamentais; e complementa que "quanto menor for a sujeição da administração às leis (de modo especial na esfera dos atos discricionários e no âmbito dos atos de governo), tanto maior virá a ser a necessidade de os órgãos administrativos observarem - no âmbito da discricionariedade de que dispõem - o conteúdo dos direitos fundamentais, que (...) contém parâmetros e diretrizes para a aplicação e interpretação dos conceitos legais indeterminados". ${ }^{67}$

63 MELLO, ob. cit., p. 36

64 Idem, p. 43.

65 SALAVERRÍA, ob. cit., p. 45.

66 SARLET, ob. cit., p. 327.

67 SARLET, ob. cit., p. 329. 
Assim, o interesse público a ser perseguido pelo agir administrativo está profundamente relacionado à proteção e garantia dos direitos fundamentais, havendo vinculação da Administração quanto à necessidade de agir em caso de riscos ou ameaças para tais direitos. A discricionariedade se situará quanto à escolha das opções razoáveis para a consecução do interesse público, devendo-se o administrador escolher a medida que lhe parece melhor. Refere QUEIRÓ que "se uma autoridade administrativa não utiliza aquela medida que, em seu juízo, é a melhor para a prossecução do interesse público específico que lhe incumbe realizar, e, pelo contrário, utiliza outra que, sendo embora lícita, por fazer parte do quadro daquelas entre as quais pode escolher, não é, em todo caso, aquela que a própria autoridade considerou a melhor para aquele fim, énos lícito concluir que esta autoridade não observou a lei, no seu mais profundo e íntimo sentido. De maneira que podemos afirmar que as autoridades administrativas só exercem legalmente o seu poder discricionário quando façam a escolha da medida a tomar em dado caso, orientando-se pelo propósito de servirem da melhor maneira o interesse público específico a realizar, e procedam de acordo com a escolha assim efetuada". ${ }^{68}$

Sob outro enfoque, TOMAZ FERNANDEZ invoca como limite ao poder discricionário, a fim de que não caia na seara da arbitrariedade, o dever de motivar o ato administrativo e a necessidade de justificação objetiva, ${ }^{69}$ posto que o poder administrativo em um Estado de Direito é sempre um poder funcional, um poder obrigado a alcançar com êxito a função para o que foi criado. ${ }^{70} \mathrm{O}$ ato, por seu turno, deve estar em conformidade com o Direito, conceito que não se confunde com o de Lei em sentido estrito. Por este motivo, embora a lei possa apresentar diversas soluções suscetíveis de escolha discricionária, o Direito acabará por apontar apenas uma decisão, a melhor de acordo com a ordem de valores que inspira o ordenamento jurídico. ${ }^{71}$ Destarte, a busca pelo interesse público remete a Administração a uma única solução justa. ${ }^{72}$

Com esta opinião concorda CELSO ANTÔNIO, conforme exposto anteriormente, expressando o autor que, se o administrador houver praticado ato discrepante do único cabível, ou se tiver eleito algum seguramente impróprio ante o

68 QUEIRÓ, ob. cit., p. 15.

69 FERNANDEZ, Tomas R. De la arbitrariedad de la administracion. Monografias Civitas, 2. ed., Madri, 1997, p. 83

70 Idem, p. 130. O autor destaca que a verificação dos elementos do ato administrativo não implica controle da discricionariedade decisória, mas apenas a comprovação de que é prévio à própria decisão e conceitualmente alheio à liberdade de eleição entre várias soluções possíveis. Da mesma forma, o controle dos fatos determinantes não constitui controle de discricionariedade, já que não existe controle algum sobre o núcleo do poder discricionário.

71 Idem, p. 151. "Toda decisión de la Administración, por discrecional que sea, es susceptible de control judicial, y esse control no es de mera legalidad, sino de juridicidad, supuesto que la Administración há de actuar 'com sometimiento plena a la Ley y al Derecho (art. 103.1 de la Constitución), amén de 'a los fines que la justifican' (art. 106.1). El juez puede llegar en su crítica y en su decisión sobre los actos discrecionales de la Administración tal lejos como el Derecho lo permita. La última palabra siempre tiene el Derecho" (p. 152).

72 FERNANDEZ, ob. cit., p. 101. 
confronto com a finalidade da norma, o Judiciário deverá prestar a adequada revisão jurisdicional, porquanto, em rigor, a Administração terá desbordado da esfera discricionária. ${ }^{73}$

Também caberá controle judicial a fim "de corrigir atos que desbordem das possibilidades abertas pela moldura normativa - nos casos em que o Judiciário verifica se os conceitos vagos ou imprecisos foram apreendidos pela Administração dentro da significação contextual que comportavam, como quando, para os mesmos fins, verifica se a opção de conveniência e oportunidade se fez sem desvio de poder, isto é, obsequiosa às finalidades da lei". ${ }^{74}$

E, uma vez constatado que o ato não atingiu a finalidade legal ou que desbordou as possibilidades abertas pela lei, ou que outra seria a única solução razoável, será possível ao Judiciário substituir a decisão reputada como ilegal?

A doutrina se debate no que diz respeito à substituição do conteúdo do ato discricionário pelo juiz. FERNANDEZ admite essa possibilidade, exemplificando que os tribunais contencioso-administrativos espanhóis não só anulam decisões administrativas que fixam preços de desapropriação, como estipulam os valores mais adequados. ${ }^{75} \mathrm{O}$ fundamento situa-se na regra constitucional de que todas as ordens jurisdicionais, sem distinção, devem "proporcionar a quien es titular de un derecho, en la medida en que sea posible prácticamente, todo aquello y precisamente aquello que tenía derecho a conseguir". ${ }^{76}$

JUAN IGARTUA SALAVERRÍA admite a interferência judicial quando se tratar de discricionariedade técnica, ${ }^{77}$ sustentando que, como o exercício desta forma de discricionariedade cuida de uma atividade de concreção e aplicação de critérios técnicos,

73 Conseqüência deste raciocínio é que "não bastará invocar a expressão legal enunciadora de conceito fluido ou que dá liberdade de fazer ou não fazer, ou que permite praticar o ato $\mathrm{A}, \mathrm{B}$ ou $\mathrm{C}$, para que o órgão controlador (interno ou externo) da legitimidade, seja o Judiciário, seja a Administração Pública, tenha que concluir que existe discrição e que, por isso, não pode ser examinado a fundo o ato, sob pena de estar-se entrando no mérito do ato administrativo. É que isto não é 'mérito' do ato administrativo. Mérito é o campo de liberdade suposto na lei e que, efetivamente, venha a remanescer no caso concreto, para que o administrador, segundo critérios de conveniência e oportunidade, se decida entre duas ou mais soluções admissíveis perante ele, tendo em vista o exato atendimento da finalidade legal, dada a impossibilidade de ser objetivamente reconhecida qual delas seria a única adequada" (ob. cit., p. 27).

74 MELLO, ob. cit., p. 27

75 FERNANDEZ, ob. cit., p. 168/169.

76 Idem, p. 170.

77 SALAVERRÍA, Juan Igartua. Discrecionalidad técnica, motivación y control jurisdicional. Editorial Civitas: Madrid, 1998, p. 15. O autor distingue discricionariedade técnica da discricionariedade administrativa genérica, aduzindo que a primeira expressa tendencialmente regras objetivamente válidas a que também a Administração deve se submeter. Assim, certos espaços discricionários passam a estar regidos por uma rede de princípios e critérios, que transformam uma atividade não regrada (discricionária) em atividade regrada e, por isso, sujeita a controle judicial (p. 27). SALAVERRÍA conceitua discricionariedade técnica da seguinte forma: "es una actividad valorativa fundamentada en reglas de una ciencia, disciplina o 'arte'; la cual se expresa en juicios que consienten un margen, aunque sea mínimo, de opinabilidad' (p. 28). 
ou seja, de uma atividade jurídica, o ordenamento jurídico não permite excluir o controle de fundo da decisão, "con lo que a los jueces compete no sólo anular sino incluso sustituir las decisiones que los órganos administrativos hubieren adoptado en el marco de la precitada discrecionalidad técnica". No entanto, esclarece que a faculdade de revisão judicial reside apenas no que diz respeito à atividade de aplicar normas aos fatos concretos. No que concerne à competência da Administração para estabelecer as normas, o controle judicial deve limitar-se à fiscalização da conformidade à lei, com possibilidade de anulação da decisão administrativa ilegal. ${ }^{78}$

CELSO ANTÔNIO BANDEIRA DE MELLO, com as ressalvas feitas sobre o que entende ser "mérito administrativo", afirma que "havendo litígio sobre a correta subsunção do caso concreto a um suposto legal descrito mediante conceito indeterminado, caberá ao Judiciário conferir se a Administração, ao aplicar a regra, se manteve no campo significativo de sua aplicação ou se o desconheceu. Verificado, entretanto, que a Administração se firmou em uma intelecção perfeitamente cabível, ou seja, comportada pelo conceito ante o caso concreto - ainda que outra também pudesse sê-lo - desassistirá ao Judiciário assumir est'outra, substituindo o juízo administrativo pelo seu próprio. É que aí haveria um contraste de intelecções, igualmente possíveis. Ora, se a intelecção administrativa não contrariava o direito - este é o pressuposto tópico sub examine - faleceria título jurídico ao órgão controlador de legitimidade para rever 0 ato ...". ${ }^{79}$

No entanto, defende a intervenção judiciária para controlar a finalidade do ato administrativo na busca da melhor solução possível e também para aferir se há correlação lógica entre a finalidade e o ato adotado. Com respeito a esta correção, CELSO ANTÔNIO afirma que o ato deve ser confrontado com as circunstâncias fáticas existentes para que o Poder Judiciário verifique se ele guarda ou não com elas a correlação lógica necessária e se tem, pois, idoneidade para alcançar a finalidade. "O resultado deste confronto pode levar, inclusive, à total disparição de discricionariedade, que embora existente ao nível da norma deixa de suster-se ante as peculiaridades de alguma situação em concreto". ${ }^{80}$

E o autor conclui que o Poder Judiciário, para cumprir sua função própria, "não se poderá lavar de averiguar, caso por caso, ao lume das situações concretas que ensejaram o ato, se, à vista de cada uma daquelas específicas situações, havia ou não discricionariedade e que extensão tinha, detendo-se apenas e tão-somente onde e quando estiver perante opção administrativa entre alternativas igualmente razoáveis, por ser in concreto incognoscível a solução perfeita para o atendimento da finalidade, isto é, do interesse consagrado pela norma" ${ }^{81}$ Trata-se de um exame de legitimidade e que impõe a fulminação dos atos - praticados embora sob o argumento da discricionariedade - 
"sempre que seja objetivamente demonstrável que a conduta adotada não foi a providência ótima almejada pela lei, pois, em casos que tais, não terá havido exercício de verdadeira discrição administrativa, mas terá ocorrido pura e simplesmente violação do Direito". 82

No que diz respeito à proteção do meio ambiente, incontroversa, como já referido, a nota de fundamentalidade do direito instituído pelo art. 225, caput, da Constituição Federal, sendo também inequívoco o dever estatal de combater a poluição em todas as suas formas. Daí que este é o interesse público a ser atingido, cabendo à Administração Pública, na seara da discricionariedade técnica, tão-somente eleger a forma, dentro de conhecimentos técnico-científicos, pela qual a degradação ambiental haverá de ser combatida. Não há que se reconhecer liberdade efetiva do administrador na escolha do momento mais conveniente e oportuno para a adoção de medidas específicas de preservação.

Veja-se que, especialmente, a obrigatoriedade do tratamento de efluentes domésticos e a disposição final do resíduo sólido urbano decorrem de expressa legislação federal e estadual, não havendo qualquer margem de discricionariedade a respeito da eleição de prioridades. Neste sentido, vale referir o posicionamento de WALLACE PAIVA MARTINS JÚNIOR, ao tratar da despoluição das águas, quando afirma que "não há lugar para invocar-se a discricionariedade administrativa porque a atividade devida é decorrente de lei que exige o prévio tratamento de esgotos domésticos e a sua conformidade com os padrões ambientais estabelecidos como condição para o lançamento nas águas com o fito de impedir a poluição". ${ }^{83}$

Portanto, em caso de omissão estatal quanto ao combate da degradação ambiental, com vistas a garantir o mínimo de qualidade ambiental necessária à dignidade da vida humana, parece-nos cabível a intervenção judicial, a fim de suprir as omissões estatais lesivas à qualidade ambiental. E sem que se argumente pela invasão por parte do Poder Judiciário de competências exclusivas do Executivo, com violação do princípio da separação dos poderes.

É que está em jogo um direito de personalidade, consistente no direito à salubridade ambiental, cujo objeto, de acordo com SENDIM, "seria uma dada característica (salubridade) do espaço-território essencial à saúde. Seria, assim, um direito de personalidade dotado de uma dimensão espácio-temporal correspondente à dimensão da coletividade a que o sujeito pertence" ${ }^{84}$ Trata-se de direito autônomo em relação ao direito à saúde e aos direitos patrimoniais, justificando-se porque a existência de um ambiente salubre e ecologicamente equilibrado representa "uma condição essencial para o completo desenvolvimento da personalidade humana. Assim, entre os bens abrangidos pela tutela geral da personalidade, prevista no art. 70 do Código Civil

83 MARTINS JÚNIOR, Wallace Paiva. Despoluição das águas. Revista dos Tribunais, v. 720, p. 58 e ss.

84 SENDIM, José de Sousa Cunhal. Responsabilidade civil por danos ecológicos. Coimbra: Coimbra, 1998, p. 35. 
(português), contar-se-iam, também, os elementos componentes da relação existencial do Homem com a Natureza". 85

Por isso, compete ao Poder Judiciário salvaguardar tais direitos, com o que não está criando políticas públicas, mas tão-somente impondo a execução daquelas já estabelecidas na Constituição e nas leis infraconstitucionais. Assim manifestou-se o Tribunal de Justiça de São Paulo, ao admitir a utilização da ação civil pública para compelir a municipalidade ao tratamento de detritos lançados nas águas de rio. $\mathrm{Na}$ ementa consta que "há interesse pertinente de toda a sociedade do lugar e órgão jurisdicional está legitimamente impulsionado a realizar a tarefa consistente em dirimir controvérsia na direção e forma previstas pela ordem jurídica municipal, diversa, portanto, de pura deliberação de prática de atos da administração, onde certamente não lhe seria lícito intervir". 86

Ademais, consoante entendimento de ÁLVARO MIRRA, "a realização de escolhas ou opções em matéria de meio ambiente e a tomada de iniciativas na utilização dos instrumentos legais de preservação ambiental não é mais incumbência privativa da Administração. Diversamente, a partir do momento em que se consagrou o direito fundamental de todos ao meio ambiente ecologicamente equilibrado e se reconheceu o meio ambiente como bem de uso comum do povo, não se pode mais conceber que decisões unilaterais do Poder Executivo sejam tomadas em desconformidade com as preocupações preservacionistas da sociedade. Assim, toda vez que a Administração não atuar de modo satisfatório na defesa do meio ambiente, omitindo-se no seu dever de agir para relegar a proteção da qualidade ambiental a questão de importância secundária, violando as normas constitucionais e infraconstitucionais que lhe impuseram a obrigatoriedade de atuar, caberá à coletividade, por intermédio de seus representantes legitimados, buscar perante o Poder Judiciário o estabelecimento da boa gestão ambiental". ${ }^{87}$

E afirma o autor que tal conclusão reside e se justifica no próprio princípio da separação de poderes, pois, "se o poder detém o poder, se ao Poder Judiciário cabe a jurisdição, é da lógica da separação de poderes o controle da Administração, sem que se possa cogitar de ingerência indevida", ${ }^{88}$ além do que, "se a separação de poderes representa uma garantia destinada a assegurar a proteção dos direitos humanos contra o arbítrio do Estado, seria no mínimo contraditório que ela fosse invocada pelos detentores do poder de administração como fundamento precisamente para negar a preservação de um direito humano fundamental - o direito ao meio ambiente ecologicamente equilibrado - que se pretende alcançar com a supressão da omissão estatal lesiva". ${ }^{89}$

85 Idem, p. 37

86 TJSP, 7 a CDPúb., AC 246.776-1, J. 22.05.1997, v.u., Rel. Des. JOVINO DE SYLOS, JTJ - LEX 203/ 20, in: MIRRA, ob. cit., p. 379.

87 MIRRA, Álvaro Luiz Valery. Ação civil pública e a reparação do dano ao meio ambiente. São Paulo: Juarez Oliveira, 2002, p. 374-374.

88 Idem, p. 380

89 Idem, p. 380. 
Apesar do posicionamento supracitado do Superior Tribunal de Justiça, já despontam alguns precedentes jurisprudenciais alinhados com a possibilidade de ajuizamento de ação civil pública para suprir as omissões estatais lesivas ao meio ambiente. Confiram-se os seguintes precedentes do Tribunal de Justiça do Paraná:

"Ação civil pública. Departamento de Estradas de Rodagem. Degradação do meio ambiente. Estrada inconcluída e não conservada. Erosão e assoreamento de cursos d'água. Apelo provido em parte. Comprovado através de laudo preparado por Instituto Ambiental Estadual que a ausência de conservação e a inconclusão de estrada não pavimentada, vinha provocando a erosão do solo em sua área de domínio e o assoreamento de cursos d'água por ela cruzados, impunha-se sua responsabilização pela indenização dos danos já causados, bem como a obrigação de repará-los, inclusive, com a imposição de multa e prazos para início e término das obras necessárias." ${ }^{90}$

"Ação civil pública. Lixão. Adequação. Dano ambiental. Prevalência do interesse difuso. Requisitos autorizadores da concessão presentes. 1 . O princípio da prevalência do meio ambiente deve ser observado em face de outros porque matéria de ordem pública. 2 . A concessão da liminar, assim, há de ser sopesada pelo julgador, pois que permanente o risco suportado pela sociedade, princípios observados no caso em testilha. 3. Considerando que o Poder Público é quem, com primazia, tem o dever de orientar-se segundo as normas ambientais constitucionais, por essa mesma razão é que se impõe a obrigação de adequação de suas providências. Agravo de instrumento desprovido."

Em sua obra, ÁLVARO MIRRA cita alguns arestos do Tribunal de Justiça de São Paulo, valendo colacionar a Apelação Cível $n^{\circ}$ 158.646-1/0, em que o Desembargador CEZAR PELUSO, da $2^{\mathrm{a}}$ Câmara Cível, entendeu que a ação civil pública constitui um meio idôneo para compelir o Poder Público a tratamento de esgoto, posto que "a saúde pública é, por sua natureza, prioritária e, a respeito, não há discricionariedade do Poder Público: sem água cujos padrões de pureza se encontrem dentro das classes de aproveitamento (...), a própria vida não é possível, como bem primeiro". ${ }^{92} \mathrm{E}$, ainda, aresto da $7^{\mathrm{a}}$ Câmara Cível do Tribunal de Justiça paulista que se assentou: "inviável a suscitada impossibilidade financeira, já que o problema (lixo urbano) deve ser tratado como uma das prioridades sociais da Administração Pública, sendo pertinente ressaltar que em matéria de meio ambiente, verificado o dano e seu agente, a ninguém é permitido se eximir do dever de repará-lo ou indenizá-lo, assim como abster-se de provocá-lo. Aliás, como bem posto na r. sentença, 'do contrário, todo aquele que causasse o dano, poderia escusar-se da obrigação reparatória ou de dever de não provocá-lo, invocando dificuldades financeiras, o que, à evidência, é inadmissível. A ordem jurídica estaria irremediavelmente comprometida". ${ }^{93}$

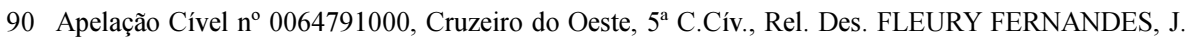
11.08.1998

91 Agravo de Instrumento $n^{\circ} 0087446800,1^{\circ}$ de maio, $6^{\mathrm{a}}$ C.Cív., Rel ${ }^{\mathrm{a}}$ Des $^{\mathrm{a}}$ ROSENE ARÃO DE CRISTO PEREIRA, J. 18.10.2000.

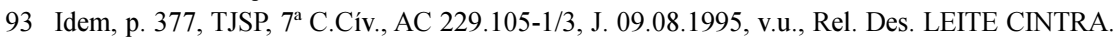


Examinando-se tais precedentes, pode-se afirmar, com MIRRA, que não há "ingerência indevida do Poder Judiciário na esfera de competência do Poder Executivo quando impõe à Administração Pública o cumprimento de obrigações de fazer tendentes à supressão da omissão estatal lesiva ao meio ambiente, pois, na realidade, quem age em iniciativas dessa natureza é a própria sociedade, e o juiz, ao ser provocado, exerce sua atribuição precípua e específica de aplicar o direito aos casos concretos". ${ }^{4}$

O Judiciário, nessas condições, não cria uma obrigação ou política pública ambiental, mas apenas determina o cumprimento e a execução de obrigações públicas já previstas na legislação protetiva do meio ambiente, procurando, desta forma, suprimir uma omissão estatal lesiva à garantia do mínimo existencial em matéria de salubridade ambiental.

\section{CONCLUSÃO}

Transportando a doutrina acima exposta para a seara da proteção ambiental, destaca-se que, se o Poder Executivo não adotar as medidas necessárias para garantir a dignidade do viver humano, em um ambiente não contaminado e ecologicamente equilibrado, estará incorrendo em omissão ilegal. Destarte, não se poderá valer do argumento da discricionariedade a fim de se escusar da adoção das medidas necessárias para assegurar um mínimo de proteção ambiental, o que deve ser compreendido como o direito humano fundamental a um ambiente onde não se verifiquem situações de risco para a vida e a saúde, e onde se possa desenvolver a personalidade humana em condições dignas.

É que a finalidade do art. 225 da Constituição Federal é garantir um direito fundamental, estando o Poder Público vinculado à observância desta finalidade. A liberdade de escolha do Administrador recairá exclusivamente sobre as opções para a execução das medidas necessárias à consecução do objetivo constitucional. Liberdade esta que, ainda assim, deverá ser pautada por critérios científicos e pela razoabilidade, tudo para que se atinja a melhor solução possível.

Destarte, havendo inércia da Administração Pública ou adoção de medidas despropositadas e insuficientes que não atendam à finalidade de proteção ambiental e garantia de dignidade de vida em um ambiente sano, cabe, a nosso ver, a intervenção do Poder Judiciário, de sorte a impor ao Executivo o dever de agir, ainda que não possa dizer - explicitamente - qual a medida mais adequada ao caso concreto, com o que estaria realmente substituindo o Poder Executivo, com possível violação ao princípio da separação dos poderes - talvez este tenha sido o equívoco dos autores das ações civis públicas julgadas pelo Superior Tribunal de Justiça, já que exigiram a condenação da Administração Pública em obrigações de fazer específicas.

Por outro lado, como na seara ambiental, as decisões situam-se na esfera científica e técnica, na grande maioria das vezes haverá apenas uma única situação a atender os 
critérios de razoabilidade, proporcionalidade, economicidade e adequação à norma, ressalvando-se ao Judiciário também controlar se não ocorreu desvio por parte da Administração Pública na escolha da medida cabível. Neste caso, entendemos que o Poder Judiciário poderá condenar a Administração Pública à obrigação de fazer genérica - de adotar as medidas adequadas para fazer cessar a causa da poluição, ou eliminar os riscos de dano irreparável ao meio ambiente, controlando-se, a posteriori, a adequação e suficiência da medida escolhida.

\section{REFERÊNCIAS BIBLIOGRÁFICAS}

ANTUNES, Paulo de Bessa. Direito ambiental. Rio de Janeiro: Lumen Juris, 1996.

BENJAMIN, Antônio Herman. Responsabilidade civil pelo dano ambiental. In: Revista de Direito Ambiental, v. 9, p. 12.

BITTENCOURT, Darlan Rodrigues; MARCONDES, Ricardo Kochinski. Lineamentos da responsabilidade civil ambiental. Revista dos Tribunais, v. 740, p. 69.

BOBBIO, Norberto. A era dos direitos. Rio de Janeiro: Campus, 1992.

BONAVIDES, Paulo. Curso de direito constitucional. 7. ed. São Paulo: Malheiros, 1997.

BORGES, Roxana. Direito ambiental e teoria jurídica no final do século XX. In: VARELLA, Marcelo Dias; BORGES, Roxana (org.). O novo em direito ambiental, Belo Horizonte: Del Rey, 1998.

CAETANO, Marcello. Manual de direito administrativo. 10. ed. Coimbra: Almedina, v. I, 1991. ESCOLA, Héctor Jorge. El interés público como fundamento del derecho administrativo. Buenos Aires: Ediciones Depalma, 1989.

FARIAS, Paulo José Leite. Competência federativa e proteção ambiental. Porto Alegre: Sérgio Antônio Fabris, 1999.

FERNANDEZ, Tomaz R. De la arbitrariedad de la administracion. Madrid: Monografias Civitas, 1997.

FIGUEIREDO, Lúcia Valle. Curso de direito administrativo. São Paulo: Malheiros.

FIORINI, Bartolomé. La discricionalidad en la admninistración pública. Buenos Aires, 1948.

FREITAS, Juarez. O controle dos atos administrativos e os princípios fundamentais. São Paulo: Malheiros, 1997.

GAVIÃO FILHO, Anízio Pires. “Ação Civil Pública. Discricionariedade administrativa. Controle externo dos atos administrativos. Limites entre discricionariedade e legalidade. Eficácia dos direitos fundamentais". Trabalho apresentado no Painel "Controle externo dos atos administrativos no direito brasileiro: limites entre discricionariedade e legalidade". In: Curso de aperfeiçoamento em ação civil pública, ESMP/RS, 6 de agosto de 1999, Porto Alegre, RS, mimeo.

MARCHESAN, Ana Maria Moreira. O princípio da prioridade absoluta aos direitos da criança e do adolescente e a discricionariedade administrativa. Revista do Ministério Público, Rio Grande do Sul, n. 44, Porto Alegre, 2001, p. 205.

MARTINS JÚNIOR, Wallace Paiva. Despoluição das águas. RT, v. 720, p. 58.

MEIRELLES, Hely Lopes. Direito administrativo brasileiro. 21. ed. São Paulo: Malheiros, 1996.

MELLO, Celso Antônio Bandeira. Discricionariedade e controle judicial. 2. ed. São Paulo: Malheiros, 1998. 
MILARÉ, Édis. Princípios fundamentais do direito do ambiente. In: Revista dos Tribunais, v. 756, p. 53.

MIRRA, Álvaro Luiz Valery. Ação civil pública e a reparação do dano ao meio ambiente. São Paulo: Juarez de Oliveira, 2002.

PEREIRA, André Gonçalves. Erro e ilegalidade no ato administrativo. Lisboa: Edições Ática, 1962.

QUEIRÓ, Afonso Rodrigues. Os limites do poder discricionário das autoridades administrativas. In: Estudos de Direito Administrativo, I, Atlântida, Ed. Coimbra, 1967.

SALAVERRÍA, Juan Igartua. Discrecionalidad técnica, motivación y control jurisdicional. Madrid: Editorial Civitas, 1998.

SARLET, Ingo Wolfgang. A eficácia dos direitos fundamentais. 1. ed. Porto Alegre: Livraria do Advogado, 1998.

SENDIM, José de Sousa Cunhal. Responsabilidade civil por danos ecológicos. Coimbra: Coimbra, 1998.

TRINDADE, Cançado. Direitos humanos e meio ambiente - paralelo dos sistemas de proteção internacional. Porto Alegre: Sérgio Antônio Fabris, 1993. 